addition, we have recorded other mountain birds at the Observatory, including several each of the Audubon's race of the Yellow-rumped Warbler and MacGillivray's' Warblers.

1. AMERICAN ORNITHOLOGISTS' UNION. 1997. Forty-first Supplement to the American Ornithologists' Union Checklist of North American Birds. The Auk 114: 542-552.
2. BUCKLEY, P.A. 2003. Williamson's Sapsucker, Cordilleran Flycatcher, and other long-distance vagrants at a Long Island, New York stopover site. North American Birds 57: 292-304.

3. HEINDEL, M.T.1996. Field identification of the Solitary Vireo complex. Birding 28: 458:471.

4. TAYLOR, P.S. and R. BISSON. 2006. Plumbeous Vireo sight record for Saskatchewan in 2004. Blue Jay 64:32-34.

\title{
UPDATE ON CATTLE EGRET AND WHITE-FACED IBIS BREEDING ACTIVITY AT WHITEWATER LAKE, MB IN 2007
}

RON BAZIN, Canadian Wildlife Service, 150 - 123 Main Street, Winnipeg, MB R3C 4W2, E-mail: <ron.bazin@ec.gc.ca>

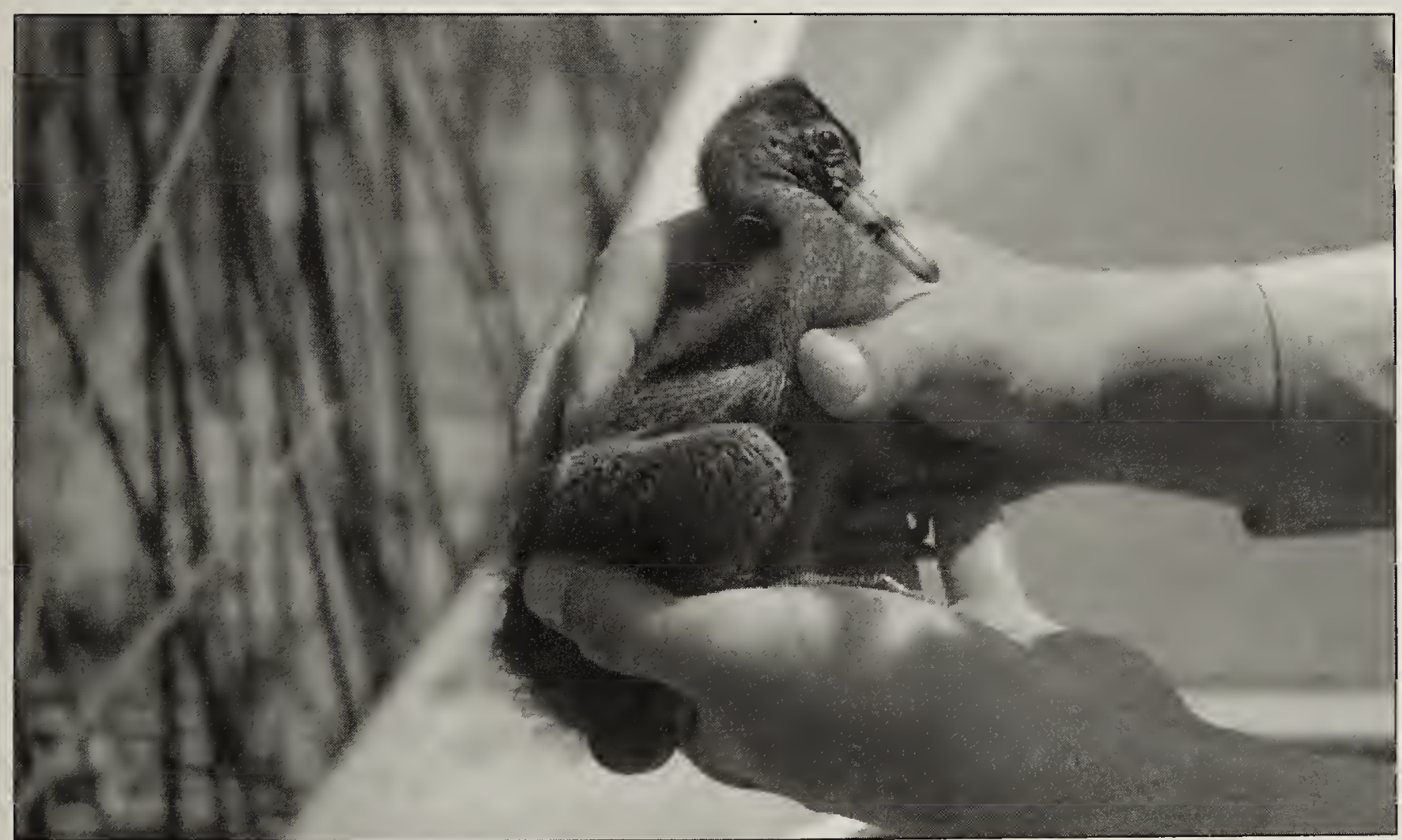

Figure 1. Immature White-faced Ibis at Whitewater Lake, MB on 9 July 2007.

Ron Bazin

Cattle Egrets and White-faced Ibis were observed nesting in Manitoba in 2007, following the first documented successful breeding in 2005 and additional observations in 2006. ${ }^{1,2}$ The 2007 records for both species are from Whitewater Lake, a 9,000 ha saline wetland in southwestern Manitoba between the towns of Boissevain and Deloraine. Whitewater Lake was the location for the first White-faced lbis breeding record in Manitoba in 2005 and the location for several small Cattle Egret colonies in 2006 1,2 . Of particular importance to a number of waterbird species, including Cattle Egrets and 
White-faced Ibis, is a large managed wetland cell located at the east end of Whitewater Lake, which has a total area of 750 ha. There is also an adjacent smaller wetland cell with an area of 150 ha. The observations reported here were recorded during two separate visits to the lake, the first on 30 May-1 June and the second on 7-9 July.

\section{Cattle Egret}

During the 30 May-1 June visit made with G.W. Beyersbergen (Canadian Wildlife Service - Edmonton), no Cattle Egrets were observed. However, three Black-crowned Night-Heron colonies were noted on the lake on 1 June, each with approximately 40 adults and active nests with eggs. Two of the colonies were located just outside the large wetland cell at the east end of the lake, whereas the third was in the southwest corner. Cattle Egrets are known to nest in association with Black-crowned Night-Herons, but none were observed during this first visit. ${ }^{3}$

On the second visit, on 7-9 July, I discovered two separate Cattle Egret colonies. One colony, with approximately 30 adults, was found within the Black-crowned Night-Heron colony discovered in the southwest corner of the lake during the first visit. This colony was in the same location as two small Cattle Egret colonies discovered in 2006. ${ }^{1}$ The Cattle Egret nests observed in this colony contained only eggs, whereas most of the Blackcrowned Night-Heron nests contained nestlings in various stages of development.

The second and larger Cattle Egret colony was also in a Black-crowned Night-Heron colony located within the large wetland cell and in the same general area as nine small colonies observed in 2006. ${ }^{1}$ The colony was centered within a zone of deep-water, emergent vegetation and was approximately $750 \mathrm{~m}$ from the nearest dyke. Approximately 100 Cattle Egret adults were observed, although more may have been hidden within the bulrush vegetation. To minimize disturbance, only the Cattle Egret nests located along the edge of the colony were checked. Those nests contained nestlings at various stages of development.

\section{White-faced Ibis}

Twelve White-faced Ibis were observed during the 30 May-1 June visit to the lake (five on 30 May and seven on 1 June), including two within the large wetland cell area. No nests were observed at this time.

During the 7- 9 July visit, I observed significantly larger numbers of Whitefaced Ibis, most within or just outside the large wetland cell. The maximum one-day count was 26 adults recorded on 9 July, all within the large wetland cell. On 8 July, 18 birds were observed within the lake itself of which nine were notably closer (within $350 \mathrm{~m}$ ) to the dyke surrounding the large wetland cell than the remaining nine which where spread more throughout the rest of the lake. An additional White-faced Ibis was observed in the cell on 8 July. Considering their location near or within the cell, if these 10 birds are part of the 26 birds observed in the cell on 9 July, this would suggest an actual count of 35 White-faced Ibis on Whitewater Lake (26 within the large cell and 9 on the remainder of the lake).

Interestingly, despite the fact that the large wetland cell covers slightly less than $10 \%$ of the entire lake area, $75 \%$ of the total estimated number of Whitefaced Ibis occurred there. A little less than half of the 20 hours of intensive search effort occurred within the large wetland cell with the remaining time 
spent covering the rest of the main lake. Though the smaller wetland cell was not searched, I viewed it from the surrounding dyke with a scope and did not observe any Cattle Egret, Whitefaced Ibis or Franklin's Gull colonies. The importance of this smaller wetland cell for other breeding waterbirds was not determined.

In the large wetland cell on 9 July, 10 White-faced lbis nests were found, all within a large and extensive Franklin's Gull colony. Most of the White-faced Ibis nests were single nests separated from one another, with the exception of three nests situated together in a tight group. Nests were located within lowto moderate-density bulrush stands and were composed primarily of bulrush stems. Nest stages varied from eggs (maximum clutch size of 5) to recently hatched young (Figure 1).

The occurrence of Cattle Egret and White-faced lbis nests in the large wetland cell highlights the importance of this managed area at the east end of Whitewater Lake as prime breeding habitat for these species. Additionally, this wetland cell provides crucial breeding habitat for other waterbird species, including a large number of Franklin's Gulls and important numbers of Eared Grebes, Blackcrowned Night-Herons, American Coots and Black Terns.

Both wetland cells, managed by Ducks Unlimited Canada, allow for control of water levels which can be used to manage key breeding habitat within the cells for these species, particularly in years when breeding habitat may not be readily available on
Whitewater Lake itself. For example, prior to 2006, Franklin's Gulls nested regularly within a large area of emergent vegetation in the centre of Whitewater Lake. A survey of that colony in 2004 provided an estimate of just over 200,000 breeding birds. As a result of significant rain events during the 2005 nesting season, there was a large increase in the water level of Whitewater Lake that resulted in the destruction of the entire Franklin's Gull colony and the complete elimination of the emergent vegetation in the centre of the lake. A significant portion of this large Franklin's Gull colony subsequently moved into the large wetland cell in the following years. Proper water level and habitat management within the wetland cells can therefore help to ensure that sufficient habitat remains available for breeding waterbirds returning to this globally significant wetland.

\section{Acknowledgements}

The author would like to thank Gerry Beyersbergen and Bryce Hoye for assistance in the field, and Gerry Beyersbergen, Paul Goossen and an anonymous reviewer for providing helpful comments on an earlier draft of this article.

1. BAZIN, R. 2006. First documented breeding record of Cattle Egrets in Manitoba. Blue Jay 64(3): 126-130.

2. BAZIN, R. and C. ARTUSO. 2006. First documented breeding record of White-faced Ibis in Manitoba. Blue Jay 64(2): 64-68.

3. TELFAIR, R.C. II. 2006. Cattle Egret (Bubulcus ibis). In The Birds of North America Online (A. Poole, Ed.). Ithaca: Cornell Laboratory of Ornithology; Retrieved from The Birds of North America Online database: http:// bna.birds.cornell.edu/BNA/account/Cattle_Egret/ 